\title{
HOST STATUS OF CRISPY-LEAF LETTUCE CULTIVARS TO ROOT-KNOT NEMATODES
}

\author{
REAÇÃO DE CULTIVARES DE ALFACE DO GRUPO CRESPA AOS NEMATOIDES \\ DE GALHAS
}

\section{Luís Fernando Franchin SGORLON'; Edgard Henrique Costa SILVA; Renato Silva SOARES'; Heloísa Oliveira BORGES'; Guilherme Matos Martins DINIZ'; Leila Trevisan BRAZ1 ${ }^{\text {; Pedro Luiz Martins SOARES }}{ }^{2}$}

1. Department of Crop Production, School of Agricultural and Veterinarian Sciences, São Paulo State University. Jaboticabal, Brazil. luisfernande310592@ hotmail.com; 2. Department of Plant Health, School of Agricultural and Veterinarian Sciences, São Paulo State University. Jaboticabal, Brazil.

\begin{abstract}
Lettuce is the main leafy vegetable grown in the world, being the crispy-leaf lettuce type predominant. With consecutive cultivation in the same area, several factors may impair yield, highlighting the damage caused by root-knot nematodes, Meloidogyne spp. This study aimed at evaluating the reaction of twenty crispy-leaf lettuce cultivars to Meloidogyne incognita race 3, M. javanica and M. enterolobii. Three experiments were conducted, one for each nematode species. The experiments were carried out in a greenhouse, in pots with sterilized substrate. The design was completely randomized with five replications. Seedlings were inoculated with 1.000 eggs and second-stage juveniles of nematode per pot, on the day of transplantation of seedlings. The tomato 'Rutgers' was used as inoculum viability control for each specie tested. The variables evaluated were: reproduction factor (FR), total number of eggs and second-stage juveniles (NTOJ) and number of eggs and second-stage juveniles per gram of root (NOJGR), 60 days after inoculation. The results showed that the cultivars Veronica, Grand Rapids and Crespa para Verão are resistant to the three nematode species. The cultivars Thaís, SRV 2005 and Marisa are resistant to $M$. incognita race 3 and M. javanica. The cultivar Black Seed Simpson is resistant to M. enterolobii. The cultivars Vanda and Mônica SF 31 are resistant to M. incognita race 3. The cultivars Crespa, Rubia, Cinderela and Veneranda are resistant to M. javanica.
\end{abstract}

KEYWORDS: Lactuca sativa L. Meloidogyne spp. Reproduction factor. Plant resistance.

\section{INTRODUCTION}

Lettuce (Lactuca sativa L.) is the most important leafy vegetable crop grown worldwide. In Brazil, the main types cultivated in order of economic importance are crispy-leaf, crisp-head, looseleaf and romaine (SALA \& COSTA, 2012). Among the lettuce groups predominantly consumed in the country, crispy-leaf type has grown considerably in the last years and corresponded to $44.55 \%$ of the volume marketed in 2014 at Ceagesp (AGRIANUAL 2016).

Cropping lettuce consecutively in the same area has triggered several problems, among them, the increase of parasitic nematode populations, mainly root-knot nematodes (Meloidogyne spp.) (CARVALHO FILHO et al., 2011).

The root-knot nematodes are phytoparasites of the root system that cause serious damage to lettuce cultivation. Several studies report the parasitic action of these nematodes in the crop (CARVALHO FILHO et al., 2011; DIAS-ARIEIRA et al., 2012; PINHEIRO et al., 2014; ROSA et al., 2015; CORREA, et al., 2015).

Lettuce plants, when attacked by these nematodes, present intense debility caused by dense formation of galls in the root system, resulting in restrictions on water and nutrients absorption and transport, becoming chlorotic, with reduced size, small leaf volume and no value for in natura consumption (CARVALHO FILHO et al., 2011).

The species Meloidogyne incognita (Kofoid \& White) Chitwood and M. javanica (Treub) Chitwood, stand out among the nematodes of importance for lettuce crop (WILCKEN et al., 2005). In the present days, Meloidogyne enterolobii Yang \& Eisenback (syn. Meloidogyne mayaguensis Rammah \& Hirschmann) has been of great concern because of its high aggressiveness in several plant species, including vegetables, fruits and ornamental crops (BRITO et al., 2007; MELO et al., 2011; ROSA et al., 2015).

The control of phytonematodes in lettuce growing areas has proved to be a challenging task. Crop rotation, a commonly recommended technique to control root-knot nematodes, is difficult to use due to wide host range and successive crops in the same areas (FERREIRA et al. 2010). Lettuce is a short-cycle crop that is predominantly consumed in natura, therefore, the use of chemical nematicides is not recommended as it may leave residues of the applied product (FERDANDEZ; KULCZYNSKI, 
2009; FERREIRA et al., 2011). Controlling these parasites is indispensable for a good crop performance, since it can cause up to $100 \%$ of production losses, depending on the infestation intensity and the cultivar susceptibility (CHACHAR; MOITA, 1996).

The use of resistant cultivars is the ideal method of control of root-knot nematodes in lettuce, since in addition to the reduction of these phytoparasites, it does not add to the grower an additional cost (MOENS et al., 2009; FERREIRA et al., 2011). Thus, the present study had as objective to evaluate twenty crispy-leaf lettuce cultivars regarding the reaction to $M$. incognita, $M$. javanica and $M$. enterolobii.

\section{MATERIAL AND METHODS}

The experiment was conducted in a greenhouse at Sitio Santa Catarina, Marília-SP, located at the geographic coordinates, latitude $22^{\circ} 14^{\prime} 59.9^{\prime \prime} \mathrm{S}$, longitude $50^{\circ} 06^{\prime} 47.7^{\prime \prime} \mathrm{W}$ and altitude of 449 meters, executed from November 2015 to January 2016.

We carried out three experiments with 20 cultivars of crispy-leaf lettuce for the following root-knot nematodes: I) $M$. enterolobii, II) $M$. incognita and III) $M$. javanica. The tests were performed in complete randomized design, with five replicates, each replicate being one pot containing one plant. The lettuce cultivars used in this study were: Cinderela (Feltrin), Crocantela (Feltrin), Mônica SF 31 (Feltrin), Rubinela (Feltrin), Veneranda (Feltrin), Ariel (Horticeres), Marisa (Horticeres), Rubia (Horticeres), Vanda (Horticeres), Black Seed Simpson (Topseed), Crespa para Verão (Topseed), Elba (Topseed), Grand Rapids (Topseed), Thaís (Sakata), Vera (Sakata), Verônica (Sakata), Banchu (Takii Seed), Crespa (Hortec), Solaris (Hortibras), and SRV 2005 (Seminis). We used the tomato 'Rutgers' as control of susceptibility.

The seeds of lettuce and tomato cultivars were sown in 200 cells expanded polystyrene trays filled with autoclaved Bio Plant ${ }^{\circledR}$ substrate. The seedlings were transplanted to 2 liters pots at 25 days after sowing. The pots were filled with a previously autoclaved mixture composed of soil, sand and tanned cattle manure, in a proportion of $1: 2: 1$.

The inoculum of each nematode species was obtained from tomato plants kept as sources of inoculum in greenhouse for 60 days. The species were identified by the perineal pattern of the females (TAYLOR; NETSCHER, 1974) and the male lip morphology (EISENBACK et al., 1991). The inoculum was multiplied in tomato 'Rutgers' plants in $2 \mathrm{~L}$ pots containing a previously autoclaved mixture composed of soil, sand and tanned cattle manure, in a proportion of 1:2:1. Highly infected tomato roots were processed according to Hussey \& Baker (1973), for the extraction of eggs and second-stage juveniles that constituted the initial inoculum. The determination of the number of eggs and second-stage juveniles in the suspension was performed with the aid of Peters chamber (SOUTHEY, 1970), under light microscope.

The lettuce seedlings were inoculated individually with 1.000 eggs and second-stage juveniles (Initial population - Ip) of the nematode population under test, on the day of transplanting. The inoculation was carried out by placing $10 \mathrm{~mL}$ of the inoculum suspension in two holes of $3 \mathrm{~cm}$ deep, near the rhizosphere of each plant. The plants were fertilized as proposed by Hoagland \& Arnon (1950).

The evaluations were performed 60 days after inoculation. The aerial part and the root system of the plants were separated. The roots were processed according to Hussey \& Baker (1973).

The final number of eggs and second-stage juveniles (Final population - Fp) in the suspension was determined with the aid of Peters chamber (SOUTHEY, 1970), under light microscope. The final and initial population was used to obtain the reproduction factor $(\mathrm{RF}=\mathrm{Fp} / \mathrm{Ip})$. The cultivars were classified according to Oostenbrink (1996), where $\mathrm{RF}$ equal to or greater than 1 the cultivar is rated as susceptible (S), and less than 1 , as resistant $(\mathrm{R})$.

The data were transformed to $\log (x+1)$. The analyzes were performed by the statistical program AgroEstat (BARBOSA; MALDONADO JÚNIOR, 2015). The means were grouped by the Scott-Knott test at $5 \%$ probability.

\section{RESULTS AND DISCUSSION}

According to the data obtained, there was a significant difference for the variables total number of eggs and second-stage juveniles (NTOJ) and number of eggs and second-stage juveniles per gram of root (NOJGR) between crispy-leaf lettuce cultivars for the three experiments (Table 1). The inoculation carried out in the experiment was successful, since there was excellent multiplication of the three species of root-knot nematodes in 'Rutgers' tomato, used as a susceptibility control for $M$. enterolobii, $M$. incognita race 3 and $M$. javanica, with FR 60.48, 12.17 and 28.44, respectively, confirming the viability of the inoculum 
The cultivars Verônica, Black Seed Simpson, Crespa para Verão, Grand Rapids, Vanda and Veneranda presented the lowest NTOJ values for $M$. enterolobii, differing significantly from the other cultivars. Among these, 'Veronica', 'Black Seed Simpson', 'Crespa para Verão' and 'Grand Rapids' obtained resistance reaction, with reproduction factors ranging from 0.36 to 0.72 (Table 1). The resistance of Verônica and Grand Rapids cultivars to M. enterolobii was also reported by Melo et al., 2011 and Rosa et al., 2015.

The susceptibility reaction to $M$. enterolobii was observed in cultivars Vanda, Veneranda, Mônica SF 31, Cinderela, Thaís, SRV 2005, Solaris, Crespa, Ariel, Elba, Banchu, Crocantela, Vera, Marisa, Rubinela and Rubia. These cultivars provided an increase in the initial nematode population, with FR ranging from 2.16 to 31.68 . The lettuce cultivar Rubia and Rubinela presented the highest values of NTOJ for M. enterolobii, followed by cultivars Marisa, Vera and Crocantela. For NOJGR, the cultivar Rubia obtained the highest value, followed by the cultivars Rubinela and Marisa. The high susceptibility of lettuce genotypes to $M$. enterolobii is reported in several studies (RODRIGUEZ et al., 2003, BITENCOURT; SILVA, 2010, MELO et al., 2011, ROSA et al., 2015).

For the reaction to $M$. incognita race 3, the cultivars Grand Rapids, Veronica, Vanda, Marisa, Monica SF 31, Crespa para Verão, SRV 2005, Thais, Ariel, Crocantela, Elba, Rubia and Crespa were the ones that provided the lowest values of NTOJ, ranging from 0 to 1800 . Among these, the cultivars Grand Rapids, Veronica, Vanda, Marisa, Monica SF 31, Crespa para Verão, SRV 2005 and Thaís were considered resistant to $M$. incognita, with reproduction factors ranging from 0 to 0.72 . In soil infested with $M$. incognita, the cultivar Grand Rapids was also highly resistant in the study conducted by Charchar \& Moita (1996).

We verified that the cultivars Vera, Banchu, Veneranda, Solaris, Cinderella, Rubinela, and Black Seed Simpson presented the highest NTOJ for $M$. incognita race 3, varying from 2880 to 6120 . The cultivars Ariel, Crocantela, Elba, Rubia, Crespa, Vera, Banchu, Veneranda, Solaris, Cinderella, Rubinela and Black Seed Simpson presented susceptibility reaction to $M$. incognita race 3 , with reproduction factor ranging from 1.08 to 6.12 .

For NOJGR, there were significant differences between cultivars. The cultivars Grand Rapids, Veronica, Vanda, Monica SF 31, Thaís, Crespa para Verão, Marisa, Crocantela, SRV 2005, Ariel, Elba and Crespa were the ones with the lowest NOJGR values ranging from 0 to 37.20. The cultivar Rubinela (NOJGR $=238.60$ ) presented the highest number of eggs and second-stage juveniles per gram of root.

Gomes (2000) reports that the resistance of the cultivar Grand Rapids to races 1, 2, 3 and 4 of $M$. incognita is controlled by a single gene locus, with predominantly additive effect, with relatively high heritability, being an important indicative that this cultivar can be used in breeding programs aiming at resistance of lettuce to $M$. incognita. Carvalho Filho et al. (2011) reported that the gene $M e$ confers resistance to $M$. incognita in the cultivar Grand Rapids.

The cultivars Verônica, Rubia, Cinderella, Grand Rapids, SRV 2005, Marisa, Crespa para Verão, Crespa, Thaís, Veneranda, Rubinela, Vanda, Ariel, Elba, Monica SF 31 and Solaris presented the lowest NTOJ values, ranging from 0 to 2160 for $M$. javanica. Among them, the cultivars Verônica, Rubia, Cinderela, Grand Rapids, SRV 2005, Marisa, Crespa para Verão, Crespa, Thaís and Veneranda presented resistance reaction to $M$. javanica species, with reproduction factor varying from 0.00 to 0.72 .

The cultivars Rubinela, Vanda, Ariel, Elba, Mônica SF 31, Solaris, Crocantela, Vera, Black Seed Simpson and Banchu showed susceptibility reaction to $M$. javanica, with reproduction factors varying from 1.08 to 5.76. Among these cultivars, Crocantela, Vera, Black Seed Simpson and Banchu presented higher NTOJ, ranging from 3240 to 5760. 
Table 1. Mean values of total number of eggs and second-stage juveniles (NTOJ), reproduction factor (FR), number of eggs and second-stage juveniles per gram of root (NOJGR), reproduction index (IR), reaction and degree of resistance (GR) of twenty cultivars of lettuce of the crispy group to Meloidogyne enterolobii, Meloidogyne incognita race 3 and Meloidogyne javanica.

\begin{tabular}{|c|c|c|c|c|c|c|c|c|c|c|c|c|}
\hline \multirow{2}{*}{ Cultivars } & \multicolumn{4}{|c|}{ Meloidogyne enterolobii } & \multicolumn{4}{|c|}{ Meloidogyne incognita raça 3} & \multicolumn{4}{|c|}{ Meloidogyne javanica } \\
\hline & NTOJ & $\mathrm{FR}$ & Reaction $^{(2)}$ & NOJGR & NTOJ & FR & Reaction $^{(2)}$ & NOJGR & NTOJ & FR & Reaction $^{(2)}$ & NOJGR \\
\hline Verônica & $360 \mathrm{a}^{(1)}$ & 0,36 & $\mathrm{R}$ & $12,43 \mathrm{a}^{(1)}$ & $0 \mathrm{a}^{(1)}$ & 0,00 & $\mathrm{R}$ & $0,00 \mathrm{a}^{(1)}$ & $0 \mathrm{a}^{(1)}$ & 0,00 & $\mathrm{R}$ & $0,00 \mathrm{a}^{(1)}$ \\
\hline Grand Rapids & $720 \mathrm{a}$ & 0,72 & $\mathrm{R}$ & $21,45 \mathrm{a}$ & $0 \mathrm{a}$ & 0,00 & $\mathrm{R}$ & $0,00 \mathrm{a}$ & $0 \mathrm{a}$ & 0,00 & $\mathrm{R}$ & $0,00 \mathrm{a}$ \\
\hline Crespa para Verão & $720 \mathrm{a}$ & 0,72 & $\mathrm{R}$ & 6,15 a & $360 \mathrm{a}$ & 0,36 & $\mathrm{R}$ & $6,00 \mathrm{a}$ & $360 \mathrm{a}$ & 0,36 & $\mathrm{R}$ & $3,40 \mathrm{a}$ \\
\hline Black Seed Simpson & $360 \mathrm{a}$ & 0,36 & $\mathrm{R}$ & 5,26 a & $6120 \mathrm{~b}$ & 6,12 & $\mathrm{~S}$ & $84,60 \mathrm{~b}$ & $5400 \mathrm{~b}$ & 5,40 & $\mathrm{~S}$ & $103,60 \mathrm{~b}$ \\
\hline Vanda & $2160 \mathrm{a}$ & 2,16 & $\mathrm{~S}$ & $19,61 \mathrm{a}$ & $0 \mathrm{a}$ & 0,00 & $\mathrm{R}$ & $0,00 \mathrm{a}$ & $1080 \mathrm{a}$ & 1,08 & $\mathrm{~S}$ & $12,00 \mathrm{a}$ \\
\hline Veneranda & $3240 \mathrm{a}$ & 3,24 & $\mathrm{~S}$ & $45,47 \mathrm{a}$ & $3960 \mathrm{~b}$ & 3,96 & $\mathrm{~S}$ & $49,00 \mathrm{~b}$ & $720 \mathrm{a}$ & 0,72 & $\mathrm{R}$ & $14,00 \mathrm{a}$ \\
\hline Mônica SF 31 & $5040 \mathrm{~b}$ & 5,04 & $\mathrm{~S}$ & $114,68 \mathrm{a}$ & $360 \mathrm{a}$ & 0,36 & $\mathrm{R}$ & $2,80 \mathrm{a}$ & $1440 \mathrm{a}$ & 1,44 & $\mathrm{~S}$ & $24,60 \mathrm{a}$ \\
\hline Cinderela & $5760 \mathrm{~b}$ & 5,76 & $\mathrm{~S}$ & $79,97 \mathrm{a}$ & $5040 \mathrm{~b}$ & 5,04 & $\mathrm{~S}$ & $66,20 \mathrm{~b}$ & $0 \mathrm{a}$ & 0,00 & $\mathrm{R}$ & $0,00 \mathrm{a}$ \\
\hline Thaís & $6480 \mathrm{~b}$ & 6,48 & $\mathrm{~S}$ & 146,49 a & $720 \mathrm{a}$ & 0,72 & $\mathrm{R}$ & $13,80 \mathrm{a}$ & $720 \mathrm{a}$ & 0,72 & $\mathrm{R}$ & $13,60 \mathrm{a}$ \\
\hline SRV 2005 & $6840 \mathrm{~b}$ & 6,84 & $\mathrm{~S}$ & $62,93 \mathrm{a}$ & $720 \mathrm{a}$ & 0,72 & $\mathrm{R}$ & $12,40 \mathrm{a}$ & $360 \mathrm{a}$ & 0,36 & $\mathrm{R}$ & $19,00 \mathrm{a}$ \\
\hline Solaris & $7560 \mathrm{~b}$ & 7,56 & $\mathrm{~S}$ & $125,16 \mathrm{a}$ & $4320 \mathrm{~b}$ & 4,32 & $\mathrm{~S}$ & $86,80 \mathrm{~b}$ & $2160 \mathrm{a}$ & 2,16 & $\mathrm{~S}$ & $14,40 \mathrm{a}$ \\
\hline Crespa & $7560 \mathrm{~b}$ & 7,56 & $\mathrm{~S}$ & $91,52 \mathrm{a}$ & $1800 \mathrm{a}$ & 1,80 & $\mathrm{~S}$ & $37,20 \mathrm{a}$ & $360 \mathrm{a}$ & 0,36 & $\mathrm{R}$ & 8,40 a \\
\hline Ariel & $9720 \mathrm{~b}$ & 9,72 & $\mathrm{~S}$ & $195,11 \mathrm{a}$ & $1080 \mathrm{a}$ & 1,08 & $\mathrm{~S}$ & $25,60 \mathrm{a}$ & $1080 \mathrm{a}$ & 1,08 & $\mathrm{~S}$ & $19,20 \mathrm{a}$ \\
\hline Elba & $10080 \mathrm{~b}$ & 10,08 & $\mathrm{~S}$ & $112,56 \mathrm{a}$ & $1080 \mathrm{a}$ & 1,08 & $\mathrm{~S}$ & $10,40 \mathrm{a}$ & 1440 a & 1,44 & $\mathrm{~S}$ & $14,00 \mathrm{a}$ \\
\hline Banchu & $10080 \mathrm{~b}$ & 10,08 & $\mathrm{~S}$ & $193,93 \mathrm{a}$ & $3960 \mathrm{~b}$ & 3,96 & $\mathrm{~S}$ & $84,00 \mathrm{~b}$ & $5760 \mathrm{~b}$ & 5,76 & $\mathrm{~S}$ & $133,20 \mathrm{~b}$ \\
\hline Crocantela & $15840 \mathrm{c}$ & 15,84 & $\mathrm{~S}$ & $130,10 \mathrm{a}$ & $1080 \mathrm{a}$ & 1,08 & $\mathrm{~S}$ & $13,80 \mathrm{a}$ & $3240 \mathrm{~b}$ & 3,24 & $\mathrm{~S}$ & $35,80 \mathrm{a}$ \\
\hline Vera & $19800 \mathrm{c}$ & 19,80 & $\mathrm{~S}$ & $460,54 \mathrm{a}$ & $2880 \mathrm{~b}$ & 2,88 & $\mathrm{~S}$ & $66,20 \mathrm{~b}$ & $3960 \mathrm{~b}$ & 3,96 & $\mathrm{~S}$ & $158,00 \mathrm{~b}$ \\
\hline Marisa & $21960 \mathrm{c}$ & 21,96 & $\mathrm{~S}$ & $829,64 \mathrm{~b}$ & $360 \mathrm{a}$ & 0,36 & $\mathrm{R}$ & $8,80 \mathrm{a}$ & $360 \mathrm{a}$ & 0,36 & $\mathrm{R}$ & $7,00 \mathrm{a}$ \\
\hline Rubinela & $27000 \mathrm{~d}$ & 27,00 & $\mathrm{~S}$ & $792,94 \mathrm{~b}$ & $5400 \mathrm{~b}$ & 5,40 & $\mathrm{~S}$ & $238,60 \mathrm{c}$ & $1080 \mathrm{a}$ & 1,08 & $\mathrm{~S}$ & $30,20 \mathrm{a}$ \\
\hline Rubia & $31680 \mathrm{~d}$ & 31,68 & $\mathrm{~S}$ & $1127,95 \mathrm{c}$ & $1800 \mathrm{a}$ & 1,80 & $\mathrm{~S}$ & $62,60 \mathrm{~b}$ & $0 \mathrm{a}$ & 0,00 & $\mathrm{R}$ & $0,00 \mathrm{a}$ \\
\hline $\mathrm{CV}(\%)$ & 15,25 & & & 19,5 & 27,51 & & & 26,68 & 32,45 & & & 31,37 \\
\hline
\end{tabular}

${ }^{(1)}$ Means followed by the same letter do not differ by Scott-Knott test at $5 \%$ probability. Analysis performed from data transformed into log (x+1). ${ }^{(2)}$ Reaction, according to Oostenbrink (1966), that is, equal to or greater than 1.0, susceptible (S) and less than 1.0, resistant (R). 
For the variable NOJGR, the cultivars Verônica, Rubia, Cinderella, Grand Rapids, Crespa para Verão, Marisa, Crespa, Vanda, Thaís, Veneranda, Elba, Solaris, SRV 2005, Ariel, Monica SF 31, Rubinela and Crocantela presented the lowest NOJGR, ranging from 0.0 to 35.80. The Black Seed Simpson, Banchu and Vera cultivars obtained the highest NOJGR, ranging from 103.60 to 158.00 .

The cultivars of the crispy group had higher levels of resistance to $M$. javanica. Charchar \& Moita (1996) also reported higher levels of resistance to $M$. javanica for the crispy group, highlighting the cultivar Grand Rapids.

The crispy lettuce cultivars Veronica, Grand Rapids and Crespa para Verão showed resistance to $M$. enterolobii, $M$. incognita race 3 and $M$. javanica, simultaneously, presenting good potential for future lettuce breeding programs. These results are in agreement with those obtained in other studies (CHARCHAR; MOITA, 1996; GOMES, 2000; MALUF et al., 2002; PINHEIRO et al., 2014), who observed the potential of crispy-leaf cultivars for resistance to root-knot nematodes.

In lettuce, the multiple resistance to the three species of Meloidogyne is probably provided by the same gene or by nearby gene loci. Unlike what occurs in other vegetables, where genes that confer resistance to $M$. incognita and $M$. javanica apparently have no effect on $M$. enterolobii (CANTU et al., 2009; BITENCOURT; SILVA, 2010; ROSA, 2010; MELO et al., 2011; ROSA et al., 2014). Good examples are tomato that possesses the $M i$ gene, conferring resistance to $M$. incognita, $M$. javanica and M. arenaria (BOITEUX et al., 2012); Capsicum, Me gene series, conferring resistance to $M$. incognita, $M$. javanica, $M$. hapla and $M$. arenaria (PINHEIRO et al., 2015).

Besides the possibility of using the resistant cultivars in lettuce breeding aiming at resistance to root-knot nematodes, the resistant crispy lettuce cultivars can be used as alternatives in planting or crop rotation in areas infested by these pathogens as they are commercial and present good productive performance.

In order to manage the root-knot nematodes, the ideal is to identify the species that are occurring in the area (CUNHA et al., 2018). In an area that only occurs $M$. enterolobii, for example, in addition to the cultivars resistant to the three species evaluated, we can recommend the planting of the cultivar Black Seed Simpson.

The identification of a nematode species requires taxonomic analysis and should be carried out by a specialized laboratory, resulting in the fact that growers still do not have the habit of sending infested root systems to identify the species present in the area, thus hindering the efficient management of this parasite (COLLANGE et al., 2011).

Thus, it is important that cultivars are resistant to as many root-knot nematode species as possible. The three species evaluated in this study are those of greater socioeconomic importance in Brazil, either by distribution in the territory or by aggressiveness. In this way, it is important to have resistant cultivars to the three species, since it can be recommended for cropping in infested areas where the occurring species is yet to be identified.

\section{CONCLUSIONS}

Based on the reproduction factor, the cultivars Thaís, SRV 2005 and Marisa are resistant to the $M$. incognita race 3 and $M$. javanica; The cultivar Black Seed Simpson is resistant to $M$. enterolobii; The cultivars Vanda and Monica SF 31 is resistant to $M$. incognita race 3; The cultivars Crespa, Rubia, Cinderella and Veneranda are resistant to $M$. javanica.

The cultivars Verônica, Grand Rapids and Crespa para Verão are resistant to $M$. incognita race 3, M. javanica and $M$. enterolobii

RESUMO: A alface é a principal hortaliça folhosa cultivada no mundo, sendo o tipo crespa mais comercializada. Com o cultivo consecutivo na mesma área, vários fatores podem prejudicar a produtividade, se destacando os danos causados pelos nematoides de galha, Meloidogyne spp. Este trabalho teve como objetivo avaliar vinte cultivares de alface, do grupo crespa, quanto a reação à Meloidogyne incognita, Meloidogyne javanica e Meloidogyne enterolobii. Foram realizados três ensaios, um para cada espécie de nematoide. Os experimentos foram conduzidos em casa de vegetação, em vaso com substrato autoclavado. O delineamento experimental foi em blocos casualizados, com cinco repetições. As plantas foram inoculadas com 1.000 ovos e eventuais juvenis de segundo estágio do nematoide, no dia do transplantio das cultivares. O tomateiro 'Rutgers' foi utilizado como padrão de viabilidade do inóculo de cada espécie de nematoide. As variáveis avaliadas foram: número total de ovos e juvenis do segundo estádio (NTOJ), fator de reprodução (FR) e número de ovos e juvenis de segundo estádio por grama de raízes (NOJGR) avaliadas 60 dias após a inoculação. Os resultados obtidos mostraram que as cultivares Verônica, Grand Rapids e Crespa para Verão foram resistentes as espécies M. enterolobii, M. incognita, M. javanica. As cultivares Thaís, SRV 2005 e Marisa foram resistentes as espécies M. 
incognita e M. javanica. A cultivar Black Seed Simpson foi resistente à M. enterolobii. Vanda e Mônica SF 31 foram resistentes à M. incognita. As cultivares Crespa, Rubia, Cinderela e Veneranda foram resistentes à M. javanica.

Palavras-chave: Lactuca sativa L.. Meloidogyne. Fator de reprodução. Resistência de plantas.

\section{REFERENCES}

AGRIANUAL. 2016. Anuário da agricultura brasileira. São Paulo: FNP Consultoria \& Comercio, 2016. p. 119.

BITENCOURT, N. V.; SILVA, G. S. Reprodução de Meloidogyne enterolobii em olerícolas. Nematologia Brasileira, v. 34, p. 181-183, 2010.

BRITO, J. A.; STANLEY, J. D.; MENDES, M. L.; CETINTAS, R.; DICKSON, D. W. Host status of selected cultivated plants to Meloidogyne mayaguensis in Florida. Journal of Nematology, v. 37, p. 65-71, 2007.

CARVALHO FILHO, J. L. S.; GOMES, L. A. A.; SILVA, R. R.; FERREIRA, S.; CARVALHO, R. R. C.; MALUF, W. R. Parâmetros populacionais e correlação entre características da resistência a nematóides de galhas em alface. Revista Brasileira de Ciências Agrárias, v. 6, p. 46-51, 2011.

https://doi.org/10.5039/agraria.v6i1a819

CORREIA, E. C. S. S.; SILVA, N.; COSTA, M. G. S.; WILCKEN, S. R. S. Reproduction of Meloidogyne enterolobii in lettuce cultivars of the American group. Horticultura Brasileira, v. 33, p. 147-150, 2015. https://doi.org/10.1590/S0102-053620150000200002

CHARCAR, J. M.; MOITA, A. W. Reação de cultivares de alface a infecção por mistura populacionais de Meloidogyne incognita raça 1 e M. javanica em condições de campo. Horticultura brasileira, v. 14, p. 185$189,1996$.

COLLANGE, B.; NAVARRETE, M.; PEYRE, G.; MATEILLE, T.; TCHAMITCHIAN, M. Root-knot nematode (Meloidogyne) management in vegetable crop production: The challenge of an agronomic system analysis. Crop Protection, v. 30, n. 10, p. 1251-1262, 2011. https://doi.org/10.1016/j.cropro.2011.04.016

CUNHA, T. G.; VISÔTTO, L. E.; LOPES, E. A.; OLIVEIRA, C. M. G.; GOD, P. I. V. G. Diagnostic methods for identification of root-knot nematodes species from Brazil. Ciência Rural, v. 48, n. 2, e20170449, 2018. https://doi.org/10.1590/0103-8478cr20170449

DIAS-ARIEIRA, C. R.; CUNHA, T. P. L.; CHIAMOLERA, F. M.; PUERARI, H. H.; BIELA, F.; SANTANA, S.M. Reaction of vegetables and aromatic plants to Meloidogyne javanica and M. incognita. Horticultura Brasileira, v. 30, p. 322-326, 2012. https://doi.org/10.1590/S0102-05362012000200023

EISENBACK, J. D.; TRIANTAPHYLLOU, H. H. Root-knot nematodes: Meloidogyne species and races. In: NICKLE, W. R (Eds). Manual of agricultural nematology. New York: USA. 1991. p. 191-274.

FERNANDES, A. M.; KULCZYNSKI, S. M. Reações de cultivares de alface a Meloidogyne incognita host status of lettuce cultivars to Meloidogyne incognita. Agrarian, v. 2, p. 143-148, 2009

FERREIRA, S.; GOMES, L. A. A.; MALUF, W. R.; CAMPOS, V. P.; DE CARVALHO FILHO, J. L. S.; SANTOS, D. C. Resistance of dry bean and snap bean cultivars to Root-knot nematodes. HortScience, v. 45, p. 320-322, 2010.

FERREIRA, S.; VIEIRA, V. L. F.; GOMES, L. A. A.; MALUF, W. R.; CARVALHO FILHO J. L. S. Identificação de linhagens avançadas de alface quanto à resistência a Meloidogyne javanica. Ciência e Agrotecnologia, v. 35, p. 270-277, 2011. https://doi.org/10.1590/S1413-70542011000200006 
GOMES, L. A. A.; MAFUF, W. R.; CAMPOS, V. P. Inherintance of de resistence reaction of lettuce cultivar 'Grand Rapids' to the southern root-knot nematode Meloidogyne incognita (Kofoid \& White) Chitwood. Euphutica, v. 114, p. 34-46, 2000.

HOAGLAND, D. R.; ARNON, D. I. The water culture method for growing plants without soils. Berkeley, California Agricultural Experimental Station. 1950. 32p.

HUSSEY, R. S.; BAKER, K. R. A comparison of methods of collecting inocula of Meloidogyne sp, including a new technique. Plant Disease Report, v. 57, p. 1025-1028, 1973.

MALUF, W. R.; AZEVEDO, S. M.; GOMES, L. A. A.; OLIVEIRA, A. C. B. Inheritance of resistance to the root-knot nematode Meloidogyne javanica in lettuce. Genetics and Molecular Research, v. 1, n. 1, p. 64-71, 2002. https://doi.org/10.4238/vol1-1gmr006

MELO, O. D.; MALUF, W. R.; GONÇALVES, J. S.; GONÇALVES NETO, A. C.; GOMES, L. A. A.; CARVALHO, R. C. Triagem de genótipos de hortaliças para resistência à Meloidogyne enterolobii. Pesquisa Agropecuária Brasileira, v. 46, p. 829-835, 2011. https://doi.org/10.1590/S0100-204X2011000800007

MOENS, M.; PERRY, N. R.; STARR, F. L. Meloidogyne species - a diverse group of novel and important plant parasites. In: PERRY, R. N.; MOENS, M.; STARR, J. L. Root-knot nematodes. Wallingford: CAB International. 2009. p.1-17. https://doi.org/10.1079/9781845934927.0001

OOSTENBRINK, M. Major characteristics of the relation between nematodes and plants. Mededlingenvoor Landb Hoogeschool Wageningen, v. 66, p. 3-46, 1966.

PINHEIRO, J. B.; PEREIRA, R. B.; CARVALHO, A. D. F.; RODRIGUES, C. S.; SUINAGA, F. A. Manejo de nematoides na cultura da alface. Brasília: Embrapa, 2013. 8 p. (Circular Técnica, 124).

PINHEIRO, J. P.; RODRIGUES, C. S.; PEREIRA, R. B.; CARVALHO, A. D. F.; SUINAGA, F. A. Avaliação preliminar de cultivares de alface para resistência ao nematoide-das-galhas (Meloidogyne spp.). Brasília: Embrapa, 2014. 20 p. (Boletim de Pesquisa e Desenvolvimento, 103).

ROSA, J. M. O.; WESTERICH, J. N.; WILCKEN, S. R. S. Reprodução de Meloidogyne enterolobii em olerícolas e plantas utilizadas na adubação verde. Revista Ciência Agronômica, v. 46, p. 826-835, 2015. https://doi.org/10.5935/1806-6690.20150071

SALA, F. C.; COSTA, C. P. Retrospectiva e tendência da alfacicultura brasileira. Horticultura Brasileira, v.30, p. 187-194, 2012. https://doi.org/10.1590/S0102-05362012000200002

SOUTHEY, J. F. Laboratory methods for work with plant and soil nematodes. $5^{\text {th }}$ ed. London UK. Ministry of Agriculture Fisheries and Food. 1970.

TAYLOR, A. L.; NETSCHER, C. An improved technique for preparing perineal patterns of Meloidogyne spp. Nematologica , v. 20, p. 268-269, 1974. https://doi.org/10.1163/187529274X00285

WILCKEN, S. R. S.; GARCIA, M. J. D. M.; SILVA, N. Resistência de alface do tipo americana a Meloidogyne incognita raça 2. Nematologia Agrícola, v. 29, p. 267-271, 2005. 